\title{
The Role of Attitude Modification Interventions in the Reduction of Orofacial Pain in Patients Undergoing Orthodontic Treatment: A Scoping Review
}

\author{
Mahmoud Mando ${ }^{1, \oplus}$ Sameh Talaat ${ }^{1,2}$ \\ ${ }^{1}$ Department of Oral Technology, School of Dentistry, University of \\ Bonn, Bonn, Germany \\ ${ }^{2}$ College of Dentistry, Future University in Egypt, New Cairo, Egypt
}

\begin{abstract}
Address for correspondence Mahmoud Mando, BDS, Department of Oral Technology, University of Bonn, Regina-Pacis-Weg, Bonn, 53113, Germany (e-mail: m_mando1995@outlook.com).
\end{abstract}

Eur J Gen Dent 2021;10:96-100.

\begin{abstract}
Keywords

- attitude modification interventions

- orofacial pain

- orthodontic pain

- pain

By summarizing evidence from existing literature, the aim of this study is to investigate the effect of attitude modification interventions in the reduction of orthodontic pain in patients undergoing orthodontic treatment. A comprehensive search strategy was implemented using both manual and electronic search methods to identify both indexed and nonindexed articles in databases as well as to reduce the possibility of excluding relevant studies by chance. The online database search strategy incorporated the following databases: PubMed, Google Scholar, and EBSCO from 1940 to May 2020. The results of this review suggest that attitude modification interventions including cognitive behavioral therapy, structured phone calls, and text messages are effective methods in the reduction of pain intensity in patients undergoing orthodontic treatment. In conclusion, attitude modification methods are promising and safe nonpharmacological interventions that can be used to control pain in patients undergoing orthodontic treatment without having any side effects or complications.
\end{abstract}

\section{Introduction}

Many patients have a negative attitude toward orthodontic treatment because of the treatment duration, expenses, and pain. Among these, pain is considered the major factor to discourage patients, end treatment, and affect their compliance. ${ }^{1,2}$ Studies have shown that $28 \%$ of patients undergoing orthodontic treatment report pain as the major factor to cease treatment. ${ }^{2}$ Pain starts to become more significant at 4 and 24 hours following the placement of archwire and gradually starts to decrease after 7 days. $^{3}$ On the other hand, several reports emphasize that more than $40 \%$ of patients continue to experience pain after 7 days of the placement of archwire. ${ }^{4}$ The application of orthodontic force to the teeth sets up a series of biological events which ends with the release of

DOI https://doi.org/ $10.1055 / \mathrm{s}-0041-1732952$ ISSN 2320-4753 many inflammatory mediators including histamine, bradykinin, prostaglandin, substance $\mathrm{p}$, and serotonin. ${ }^{5,6}$ These inflammatory mediators stimulate the nerve endings to induce pain. Orthodontists usually prescribe analgesics to control pain and discomfort resulted from the orthodontic treatment, mostly ibuprofen and paracetamol. ${ }^{7-9}$ However, these analgesics can block the inflammatory pathway and interfere with the tooth movement. ${ }^{10}$ In addition, they have negative side effects and contraindications. Recently, many nonpharmacological methods have been introduced to alleviate pain and reduce discomfort including low-level laser therapy, ${ }^{11,12}$ vibratory device, ${ }^{13}$ cognitive therapy, ${ }^{14,15}$ and psychological interventions. ${ }^{16}$

Attitude modification interventions are promising nonpharmacological safe methods to reduce pain and discomfort

(c) 2021. European Journal of General Dentistry.

This is an open access article published by Thieme under the terms of the Creative Commons Attribution-NonDerivative-NonCommercial-License, permitting copying and reproduction so long as the original work is given appropriate credit. Contents may not be used for commercial purposes, or adapted, remixed, transformed or built upon. (https://creativecommons.org/licenses/by-nc-nd/4.0/).

Thieme Medical and Scientific Publishers Pvt. Ltd. A-12, 2nd Floor, Sector 2, Noida-201301 UP, India 
in patients receiving orthodontic treatment. Psychological factors have a significant influence on the perception of pain. Since perceived pain intensity and degree of pain tolerance are influenced by cognition, personality, and past experience. ${ }^{17}$ Therefore, by summarizing evidence from the existing literature, the aim of this study is to investigate the effect of different attitude modification interventions on the intensity of pain in patients undergoing orthodontic treatment.

\section{Materials and Methods}

A comprehensive search strategy was implemented using both manual and electronic search methods to identify both indexed and nonindexed articles in databases as well as to reduce the possibility of excluding relevant studies by chance. The online database search strategy incorporated the following databases: PubMed, Google Scholar, and EBSCO from 1940 to May 2020. The manual hand search incorporated the following journals: Journal of Orthodontics (2005-2020), European Journal of Orthodontics (2009-2020), American Journal of Orthodontic and Dentofacial Orthopedics
(2000-2020), and Angle Orthodontist (1990-2020). Articles were comprehensively examined against the inclusion and exclusion criteria, and only studies involving patients: (1) undergoing orthodontic treatment, (2) minimum age of 10 years, (3) receiving an attitude modification intervention to control the resulted pain and discomfort, (4) no oral disease which alters pain perception, and (5) currently not taking antibiotics and analgesics were included in this review. Abstracts, titles, and subsequently full texts of potential articles were examined carefully by two authors to make sure they were eligible to meet the inclusion criteria. Furthermore, references of all reviewed articles were assessed carefully for their eligibility to meet the inclusion criteria.

\section{Results}

The flowchart in - Fig. 1 identified the included and excluded articles at each stage. Four hundred and eight articles were assessed including 394 articles from the electronic databases, 12 from the manual hand search, and 2 articles from the reference lists. Fifty articles were duplicates, and 335 did

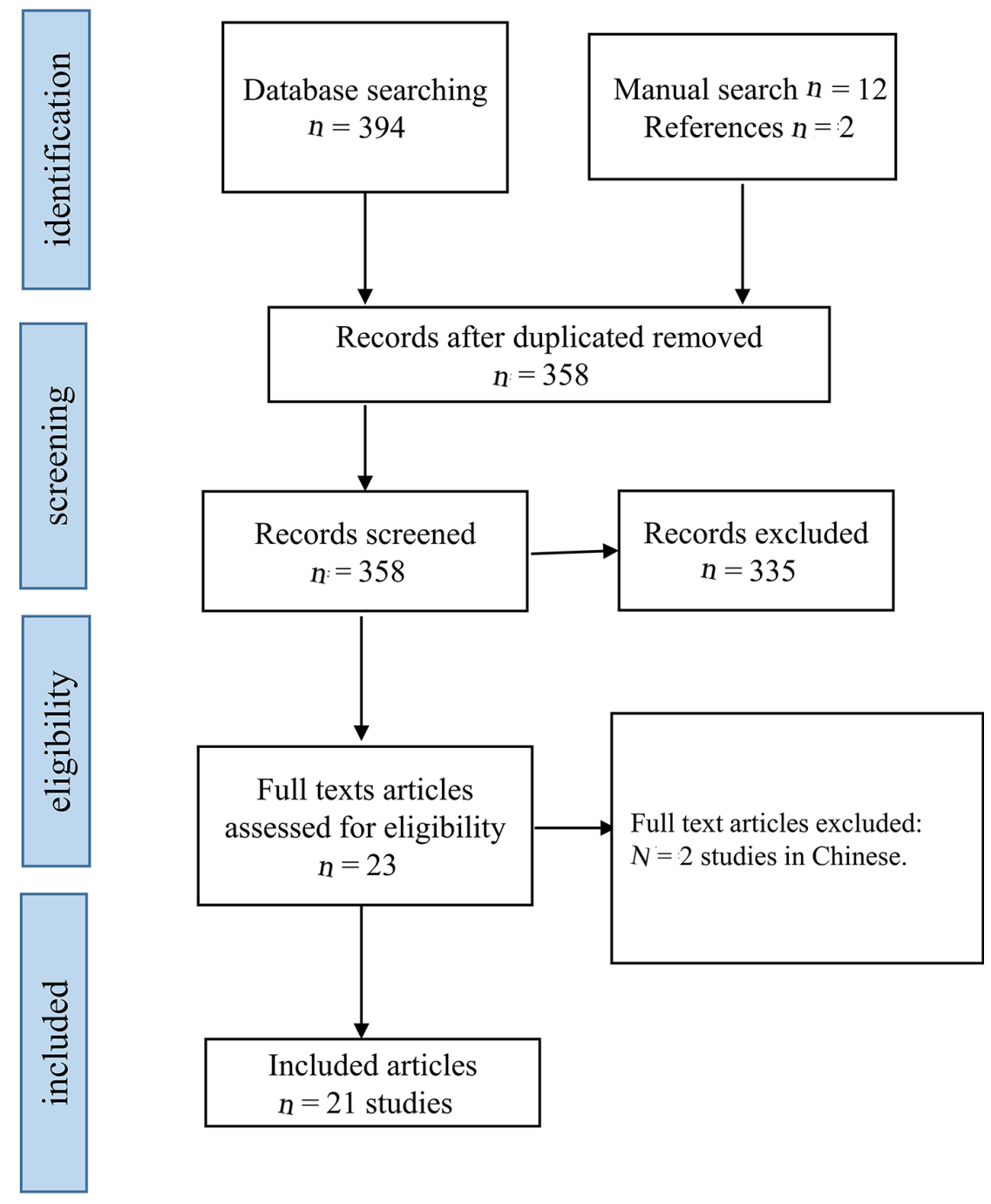

Fig. 1 A flowchart describing the search methodology and number of articles included/excluded at each step. 
not relate to the research question, thus leaving 23 articles for potential inclusion in the study. Following the inspection of the full texts of these articles, two studies were not written in English. This means only 21 studies were included in the review for further analysis. Three studies compared the cognitive behavioral therapy to patients who did not receive any treatment and revealed a statistical significance reduction in the intensity of pain between the two groups. ${ }^{14,18,19}$ Thus, cognitive behavioral therapy was an effective method in the reduction of orthodontic pain in patients undergoing orthodontic treatment. In all these three studies, patients in the cognitive behavior therapy groups were asked to perform self-practice cognitive behavior therapy skills for 15 minutes. These include daily relaxation training procedures (15 minutes) which were taught in an audio program with soft background music and played at patients' homes when orthodontic pain occurred. Furthermore, two studies investigated the role of structured phone calls in the reduction of orthodontic pain..$^{20,21}$ Among these, one study revealed a statistically significant reduction in the level of pain intensity in the structured phone calls group compared with the control group. ${ }^{21}$ The structured phone calls were composed of the following points: the importance of maintaining positive attitude, oral hygiene, diet, reassurance, pain level, and patient's well-being. On the other hand, a study by Teifer et al compared the role of courtesy phone calls only in the reduction of orthodontic pain to $600 \mathrm{mg}$ of acetaminophen and revealed that phone calls are as effective as $600 \mathrm{mg}$ acetaminophen in the reduction of orthodontic pain. ${ }^{23}$ However, this reduction in pain intensity was not statistically significant. Two studies investigated the role of text messages in the reduction of orthodontic pain and revealed a reduction of pain intensity in the test messages group compared with patients who did not receive any treatment. ${ }^{20,23}$ However, this reduction in pain intensity was not statistically significant. Patients in the text message groups received a standardized and structured text messages offering encouragement to the patients and stressing the importance of a positive attitude toward orthodontic treatment. Only one study directly compared the effect of text messages to structured phone calls and emphasized that structured phone calls are more effective in the reduction of orthodontic pain than text messages ${ }^{20}$ (-Table 1).

\section{Discussion}

According to our knowledge, this is the first scoping review to investigate the effect of attitude modification interventions in the reduction of orthodontic pain. The results of this review suggest that attitude modification interventions including cognitive behavioral therapy, structured phone calls, and text messages are effective methods to control pain in patients undergoing orthodontic treatment. Three studies compared the cognitive behavioral therapy to control patients who did not receive any treatment and revealed a significant reduction

Table 1 Summarized published data of the studies included in this scoping review

\begin{tabular}{|c|c|c|c|c|c|}
\hline Study ID & $\begin{array}{l}\text { Participantssize, } \\
\text { gender, age(y), } \\
\text { dropout }\end{array}$ & Interventions & Mode of intervention & $\begin{array}{l}\text { Method of pain } \\
\text { assessment }\end{array}$ & Author's conclusion \\
\hline $\begin{array}{l}\text { Bartlett et } \\
\text { al, } 2005^{22}\end{array}$ & $\begin{array}{l}N=150 \text { patients } \\
\text { (69 males, } 81 \\
\text { females) } \\
\text { Mean age }(\mathrm{y}) \\
15.9 \\
\text { No drop out }\end{array}$ & $\begin{array}{l}\text { Group } 1 \\
\text { Structured telephone } \\
\text { calls } \\
\text { Group } 2 \\
\text { Attention telephone } \\
\text { calls } \\
\text { Group } 3 \\
\text { Control }\end{array}$ & $\begin{array}{l}\text { Group } 1 \\
\text { Structured telephone } \\
\text { calls daily and } 4 \text { hours } \\
\text { after initial archwire } \\
\text { placement } \\
\text { Group } 2 \\
\text { attention telephone } \\
\text { calls only made daily } \\
\text { and } 4 \text { hours after initial } \\
\text { archwire placement } \\
\text { Group } 3 \\
\text { Control }\end{array}$ & VAS & $\begin{array}{l}\text { Structured phone calls } \\
\text { significantly reduce } \\
\text { orthodontic pain com- } \\
\text { pared with the attention } \\
\text { calls only and the control } \\
\text { group }\end{array}$ \\
\hline $\begin{array}{l}\text { Wang et } \\
\text { al, } 2012^{15}\end{array}$ & $\begin{array}{l}N=450 \text { patients } \\
\text { Mean age }(y) \\
16.8 \\
21 \text { drop out }\end{array}$ & $\begin{array}{l}\text { Group } 1 \\
\text { Cognitive behavioral } \\
\text { therapy (CBT) } \\
\text { Group } 2 \\
\text { Ibuprofen } \\
\text { Group } 3 \\
\text { Control }\end{array}$ & $\begin{array}{l}\text { Group } 1 \\
\text { self-practice CBT skills at } \\
\text { home for } 15 \text { minutes } \\
\text { Group } 2 \\
\text { Ibuprofen } 300 \mathrm{mg} \\
\text { Group } 3 \\
\text { Control }\end{array}$ & VAS & $\begin{array}{l}\text { Cognitive behavioral } \\
\text { therapy is as effective as } \\
\text { ibuprofen in orthodon- } \\
\text { tic pain management, } \\
\text { indicating its clinical } \\
\text { application potential }\end{array}$ \\
\hline $\begin{array}{l}\text { Keith et al, } \\
2013^{24}\end{array}$ & $\begin{array}{l}N=39 \text { patients } \\
\text { (14 males, } 25 \\
\text { females) } \\
\text { Mean age }(y) \\
13.4 \\
\text { No drop out }\end{array}$ & $\begin{array}{l}\text { Group } 1 \\
\text { Text messages } \\
\text { Group } 2 \\
\text { Control }\end{array}$ & $\begin{array}{l}\text { Group } 1 \\
\text { Text message sent daily } \\
\text { and } 4 \text { hours after initial } \\
\text { wire placement } \\
\text { Group } 2 \\
\text { Control }\end{array}$ & VAS & $\begin{array}{l}\text { Text messages sent from } \\
\text { orthodontic office was } \\
\text { effective in the reduction } \\
\text { of orthodontic pain }\end{array}$ \\
\hline
\end{tabular}


Table 1 (continued)

\begin{tabular}{|c|c|c|c|c|c|}
\hline Study ID & $\begin{array}{l}\text { Participants } \\
\text { size, gender, age } \\
\text { (y), dropout }\end{array}$ & Interventions & Mode of intervention & $\begin{array}{l}\text { Method of pain } \\
\text { assessment }\end{array}$ & Author's conclusion \\
\hline $\begin{array}{l}\text { Teifer et al, } \\
2014^{23}\end{array}$ & $\begin{array}{l}N=120 \\
\text { (43 males, } 64 \\
\text { females) } \\
13 \text { drop out }\end{array}$ & $\begin{array}{l}\text { Group } 1 \\
\text { Pre and post } 600 \mathrm{mg} \\
\text { acetaminophen } \\
\text { Group } 2 \\
\text { Pre-placebo } \\
\text { and } 600 \mathrm{mg} \\
\text { post-acetaminophen } \\
\text { Group } 3 \\
\text { Pre- } 600 \mathrm{mg} \\
\text { acetaminophen } \\
\text { post-placebo } \\
\text { Group } 4 \\
\text { Pre- and post-placebo } \\
\text { Group } 5 \\
\text { Pre- and post-cour- } \\
\text { tesy phone calls } \\
\text { Group } 6 \\
\text { Control }\end{array}$ & $\begin{array}{l}\text { Group } 1 \\
600 \text { mg acetaminophen } \\
\text { before arch wire } \\
\text { placement and after } \\
\text { recording VAS } \\
\text { Group } 2 \\
\text { Placebo before archwire } \\
\text { placement and } 600 \text { mg } \\
\text { acetaminophen after } \\
\text { recording VAS } \\
\text { Group } 3 \\
600 \text { mg acetaminophen } \\
\text { before arch wire place- } \\
\text { ment and placebo after } \\
\text { recording VAS } \\
\text { Group } 4 \\
\text { Placebo before archwire } \\
\text { placement and placebo } \\
\text { after recording VAS } \\
\text { Group } 5 \\
\text { Courtesy phone calls } \\
\text { before arch wire } \\
\text { placement and after } \\
\text { recording VAS } \\
\text { Group } 6 \\
\text { Control }\end{array}$ & VAS & $\begin{array}{l}\text { Acetaminophen, placebo, } \\
\text { courtesy telephone calls, } \\
\text { and no treatment were } \\
\text { all equally effective in } \\
\text { controlling orthodontic } \\
\text { pain }\end{array}$ \\
\hline $\begin{array}{l}\text { Sawada et } \\
\text { al, } 2015^{20}\end{array}$ & $\begin{array}{l}N=32 \\
(16 \text { males, } 16 \\
\text { females } \\
\text { Mean age }(y) \\
28.4 \\
\text { No drop out }\end{array}$ & $\begin{array}{l}\text { Group1 } \\
\text { Cognitive behavioral } \\
\text { therapy (CBT) } \\
\text { Control Group } 2 \\
\text { Control }\end{array}$ & $\begin{array}{l}\text { Group } 1 \\
\text { self-practice CBT skills at } \\
\text { home for } 15 \text { minutes } \\
\text { Group } 2 \\
\text { Control }\end{array}$ & VAS & $\begin{array}{l}\text { Cognitive behavioral } \\
\text { therapy was shown to be } \\
\text { effective in the manage- } \\
\text { ment of orthodontic pain } \\
\text { and could merit clinical } \\
\text { application }\end{array}$ \\
\hline $\begin{array}{l}\text { Cozzani et } \\
\text { al, } 2016^{21}\end{array}$ & $\begin{array}{l}N=150 \\
\text { ( } 43 \text { males, } 41 \\
\text { females) } \\
\text { mean age (y) } \\
13.3 \\
8 \text { drop out }\end{array}$ & $\begin{array}{l}\text { Group } 1 \\
\text { Control } \\
\text { Group } 2 \\
\text { Text messages } \\
\text { Group } 3 \\
\text { Structures phone calls }\end{array}$ & $\begin{array}{l}\text { Group } 1 \\
\text { Control } \\
\text { Group } 2 \\
\text { Text messages were } \\
\text { sent daily and 5-7 hours } \\
\text { after bonding by the } \\
\text { orthodontist } \\
\text { Group } 3 \\
\text { Structured phone calls } \\
\text { were made daily and } \\
5-7 \text { hours after bonding } \\
\text { by the orthodontist }\end{array}$ & VAS & $\begin{array}{l}\text { Patients in the structured } \\
\text { telephone calls and the } \\
\text { text messages groups } \\
\text { reported less pain com- } \\
\text { pared with the control } \\
\text { group }\end{array}$ \\
\hline $\begin{array}{l}\text { Huang et } \\
\text { al, } 2016^{19}\end{array}$ & $\begin{array}{l}N=36 \\
\text { Mean age }(y) \\
22 \\
\text { No drop out }\end{array}$ & $\begin{array}{l}\text { Group } 1 \\
\text { Cognitive behavioral } \\
\text { therapy (CBT) } \\
\text { Group } 2 \\
\text { Brainwave music } \\
\text { therapy } \\
\text { Group } 3 \\
\text { Control }\end{array}$ & $\begin{array}{l}\text { Group } 1 \\
\text { self-practice CBT skills at } \\
\text { home for } 15 \text { minutes } \\
\text { Group } 2 \\
\text { Brain wave music ther- } \\
\text { apy for } 15 \text { minutes } \\
\text { Group } 3 \\
\text { Control }\end{array}$ & VAS & $\begin{array}{l}\text { Both cognitive behavioral } \\
\text { therapy and brainwave } \\
\text { music were effective in } \\
\text { the reduction of ortho- } \\
\text { dontic pain }\end{array}$ \\
\hline
\end{tabular}

Abbreviation: VAS, Visual Analogue Scale.

in the intensity of perceived pain. ${ }^{14,18,19}$ However, both the Huang et al ${ }^{19}$ study and the Sawada et al ${ }^{20}$ study had a relatively small sample size; in addition, the gender distribution in the Huang et $\mathrm{al}^{19}$ study and the Wang et al ${ }^{15}$ study was not stated clearly. On the other hand, using cognitive behavioral therapy as an intervention to reduce the intensity of pain in orthodontic patients may interfere with the patient's willingness and compliance to continue the treatment due to the addition of more expenses. Therefore, it is of great importance to compare the cost-effectiveness of cognitive behavioral therapy to other noninvasive interventions. We recommend future studies evaluating the effect of cognitive behavioral therapy on the level of pain intensity in patients undergoing orthodontic treatment to be ascertained of the effect of this intervention 
using functional magnetic resonance imaging rather than the patients' own perception of pain to accurately identify the neural functional activities before and after treatment. Three studies compared the efficacy of structured phone calls to patients who did not receive any treatment and emphasized a significant reduction in the level of pain intensity. ${ }^{20-22}$ However, the Cozzani et $\mathrm{l}^{21}$ and Teifer et $\mathrm{al}^{23}$ studies had a small sample size. Two studies compared the efficacy of text messages to patients who did not receive any intervention and revealed a reduction in the intensity of pain. ${ }^{20,23}$ However, both studies had a small sample size. Furthermore, only one study compared between the efficacy of structured phone calls and the text messages and revealed that structured phone calls are more effective in the reduction of orthodontic pain than the text messages..$^{20}$ However, as mentioned earlier, the sample size of this study was small. Therefore, to draw a better conclusion, it is recommended to conduct better designed studies with large sample size in the future. For better understanding of the role of attitude modification interventions in the reduction of pain intensity, future studies should concentrate more on the level of perceived pain at different functions since sensation of pain during biting was different from the pain experienced when jaws at rest. ${ }^{24,25}$

\section{Conclusion}

Fifteen-minute self-practiced cognitive behavior therapy, structured phone calls, and text messages are effective and safe methods in the reduction of orofacial pain in patients undergoing orthodontic treatment.

Standardized and structured phone calls are more effective in the reduction of orthodontic pain than text messages.

To base our practice on scientific evidence, well-designed studies with good sample size are needed to investigate the effect of attitude modification interventions on the intensity of pain in patients undergoing orthodontic treatment.

\section{Funding \\ None.}

\section{Conflict of Interest}

None declared.

\section{References}

1 Jones ML. An investigation into the initial discomfort caused by placement of an archwire. Eur J Orthod 1984;6(1):48-54

2 Oliver RG, Knapman YM. Attitudes to orthodontic treatment. Br J Orthod 1985;12(4):179-188

3 Wilson S, Ngan P, Kess B. Time course of the discomfort in young patients undergoing orthodontic treatment. Pediatr Dent 1989;11(2):107-110

4 Bergius M, Berggren U, Kiliaridis S. Experience of pain during an orthodontic procedure. Eur J Oral Sci 2002;110(2):92-98

5 Krishnan V, Davidovitch Z. Cellular, molecular, and tissue-level reactions to orthodontic force. Am J Orthod Dentofacial Orthop 2006;129(4):469.e1-469.e32

6 Arias OR, Marquez-Orozco MC. Aspirin, acetaminophen, and ibuprofen: their effects on orthodontic tooth movement. Am J Orthod Dentofacial Orthop 2006;130(3):364-370
7 Bradley RL, Ellis PE, Thomas P, Bellis H, Ireland AJ, Sandy JR. A randomized clinical trial comparing the efficacy of ibuprofen and paracetamol in the control of orthodontic pain. Am J Orthod Dentofacial Orthop 2007;132(4):511-517

8 Bernhardt MK, Southard KA, Batterson KD, Logan HL, Baker KA, Jakobsen JR. The effect of preemptive and/or postoperative ibuprofen therapy for orthodontic pain. Am J Orthod Dentofacial Orthop 2001;120(1):20-27

9 Khalaf K, Mando M. Effect of drugs on orthodontic tooth movement in human beings: a systematic review of randomized clinical trials. Open Dent J 2019;13:22-32

10 Sari E, Olmez H, Gürton AU. Comparison of some effects of acetylsalicylic acid and rofecoxib during orthodontic tooth movement. Am J Orthod Dentofacial Orthop 2004;125(3):310-315

11 McAlinden RL, Ellis PE, Sandy JR. Report of an adverse incident in a randomized clinical trial. J Orthod 2005;32(3):203-205

12 Fujita S, Yamaguchi $M$, Utsunomiya $T$, Yamamoto $H$, Kasai K. Low-energy laser stimulates tooth movement velocity via expression of RANK and RANKL. Orthod Craniofac Res 2008;11(3):143-155

13 Guram G, Reddy RK, Dharamsi AM. Syed Ismail PM, Mishra S, Prakashkumar MD. Evaluation of low-level laser therapy on orthodontic tooth movement: a randomized control study. Contemp Clin Dent 2018;9(1):105-109

14 Marie SS, Powers M, Sheridan JJ. Vibratory stimulation as a method of reducing pain after orthodontic appliance adjustment. J Clin Orthod 2003;37(4):205-208, quiz 203-204

15 Wang J, Jian F, Chen J, et al. Cognitive behavioral therapy for orthodontic pain control: a randomized trial. J Dent Res 2012;91(6):580-585

16 Wang J, Wu D, Shen Y, et al. Cognitive behavioral therapy eases orthodontic pain: EEG states and functional connectivity analysis. Oral Dis 2015;21(5):572-582

17 Fleming PS, Strydom H, Katsaros C, et al. Non-pharmacological interventions for alleviating pain during orthodontic treatment. Cochrane Database Syst Rev 2016;12:CD010263

18 Mbizvo GK, Nolan SJ, Nurmikko TJ, Goebel A. Placebo responses in long-standing complex regional pain syndrome: a systematic review and meta-analysis. J Pain 2015;16(2):99-115

19 Huang R, Wang J, Wu D, et al. The effects of customised brainwave music on orofacial pain induced by orthodontic tooth movement. Oral Dis 2016;22(8):766-774, 23

20 Sawada A, Usui N, Shimazaki K, et al. The effects of cognitive behavioral therapy on experimental orthodontic pain. Orthod Waves 2015;7:10-12

21 Cozzani M, Ragazzini G, Delucchi A, et al. Self-reported pain after orthodontic treatments: a randomized controlled study on the effects of two follow-up procedures. Eur J Orthod 2016;38(3):266-271

22 Bartlett BW, Firestone AR, Vig KW, Beck FM, Marucha PT. The influence of a structured telephone call on orthodontic pain and anxiety. Am J Orthod Dentofacial Orthop 2005;128(4): 435-441 doi:10.1016/j.ajodo.2004.06.033

23 Teifer ND, Oesterle LJ, Shellhart WC, et al. Effectiveness of pre- and post-archwire insertion acetaminophen vs. non-pharmacologic management of pain during orthodontic tooth movement. Int J Dent Oral Sci 2014;2(1):1-5 doi:10.19070/2377-8075-140001

24 Keith DJ, Rinchuse DJ, Kennedy M, Zullo T. Effect of text message follow-up on patient's self-reported level of pain and anxiety. Angle Orthod 2013;83(4):605-610

25 Alshammari AK, Huggare J. Pain relief after orthodontic archwire installation-a comparison between intervention with paracetamol and chewing gum: a randomized controlled trial. Eur J Orthod 2019;41(5):478-485 